\title{
AN UPDATE ON COLOR IN GEMS. PART 2: COLORS INVOLVING MULTIPLE ATOMS AND COLOR CENTERS
}

By Emmanuel Fritsch and George R. Rossman

This is the second part in a three-part series on the origin of color in gem materials. This article discusses colors produced by (1) processes that involve multiple atoms (e.g., blue sapphire, organic products), and (2) a variety of defect structures that are generally created by irradiation (natural or artificial), known collectively as "color centers" (e.g., green diamond). :

\section{ABOUT THE AUTHORS}

Dr. Fritsch is research scientist at the Gernological Institute of America, Santa Monica, California. Dr. Rossman is professor of mineralogy at the California Institute of Technology, Pasadena, California.

Acknowledgments: E.F. wishes to thank Professor Georges Calas, of the University of Paris VII, for his help and encouragement in writing the original French version of this article. Special acknowledgment is given to Pat Gray for typing the manuscript and improving the translation. Particular appreciation is due to Laurel Bartlett and John Hummel for their constructive comments on this article. Jan Newell and Peter Johnston drew the line illustrations.

(1) 1988 Gemological Institute of America
Tn the first part of this series (Fritsch and Rossman, 1987),

1 we reviewed how absorption of light by a dispersed metal ion such as chromium $\left(\mathrm{Cr}^{3+}\right)$ can produce color in a gem material such as ruby. However, color in gems is also commonly produced by a variety of processes that involve the combined presence of two or more ions le.g., chargetransfer processes), or by irradiation sometimes combined with heating (the formation of a "color center"). In this article, we will describe and explain these mechanisms through a variety of examples, some of which are illustrated in figure 1 . The reader who desires more information about the origin of color in gem materials will find the reviews by Nassau (1975), Loeffler and Burns (1976), Marfunin (1979), and Fritsch (1985) particularly helpful. It should be noted that in most cases, color-causing absorption bands are so broad that they cannot be well resolved with a hand spectroscope. If visible, they usually appear as a broad smudge or as a gradual darkening toward one end of the visible range.

\section{PROCESSES INVOLVING MULTIPLE ATOMS}

Charge Transfer: When an Electron Jumps from One Atom to Another. Color is caused by dispersed metal ions when electrons undergo transitions between atomic orbitals confined to a single ion (see part 1 of this series, Fritsch and Rossman, 1987). During this transition, the electrons never leave the central atom. There are, however, a number of different ways that electrons can jump from one atom to another. When this happens, spectacular colorations may result. One of these processes is called charge transfer because it can be described in simple terms as a mechanism that transfers a negative charge (i.e., an electron) from one atom to another.

When an Electron Visits Its Nearest Neighbor: Oxygen $\rightarrow$ Metal Charge Transfer. Heliodor, the golden variety of 


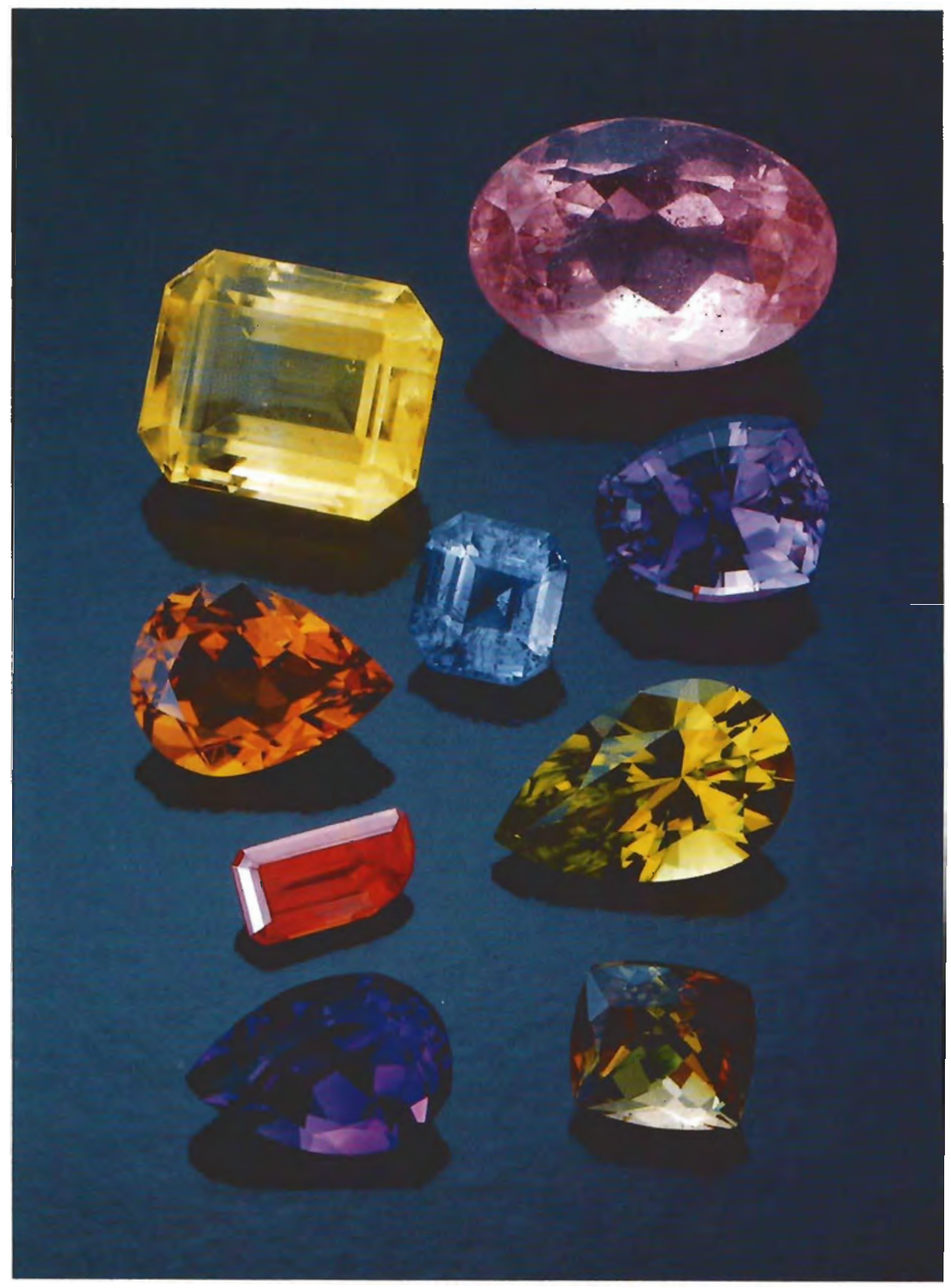

Figure 1. Colors in gem materials can be caused by a number of different processes. This article concentrates on colors caused by processes involving multiple atoms and color centers. Examples of such colorations are illustrated here (see tables 1 and 2 for the specific origin of color for each stone). Clockwise, from top right: pink fluorite, violet scapolite, greenish yellow tourmaline, andalusite, amethyst, crocoite, citrine, and yellow fluorite, with blue kyanite in the center. Stones are from the GIA collection or courtesy of Pete Flusser, Overland Gems, Inc. Photo (C) Tino Hammid.

beryl (see figure 2), is colored by $\mathrm{Fe}^{3+}$ as it interacts with other atoms in the beryl structure. The transitions confined to the $\mathrm{Fe}^{3+}$ ion absorb in the blue and violet portion of the spectrum; they are very weak and make only a minor contribution to the color. The deep yellow of heliodor is caused mainly by an extremely strong absorption centered in the ultraviolet that extends into the blue end of the visible spectrum and absorbs violet and blue (Loeffler and Burns, 1976). This ultraviolet absorption is due not to $\mathrm{Fe}^{3}+$ alone but rather to an interaction between $\mathrm{Fe}^{3+}$ and its oxygen neighbors in the beryl structure. The color results from light absorbed through the transfer of electrons from the oxygen ions to the iron ion. This color can also be induced artificially by the irradiation of blue beryl (see Fritsch and Rossman, 1987).

Usually oxygen $\rightarrow$ metal charge-transfer absorptions are centered in the near ultraviolet and are broad enough to extend into the blue end of the visible spectrum, producing yellow to orange to brown colors. Their energy is fairly independent of the nature of the host mineral. The $\mathrm{O}^{2-} \rightarrow \mathrm{Fe}^{3+}$ absorption described above for beryl is found at 


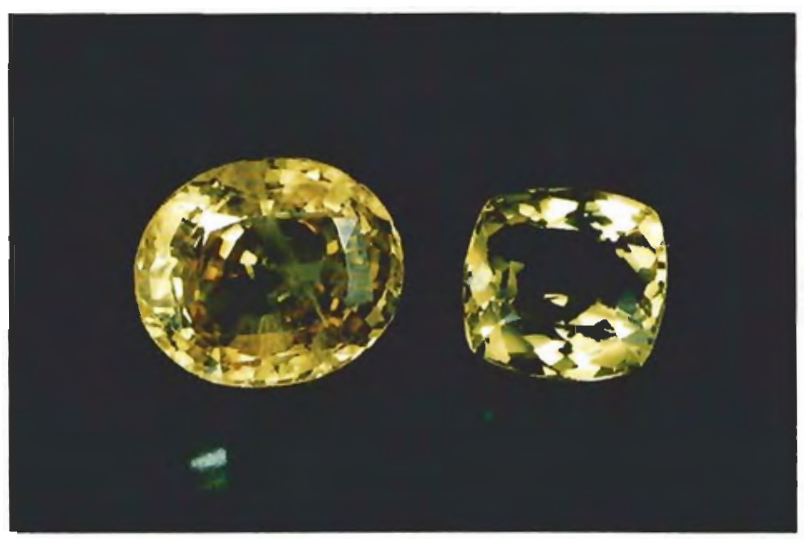

Figure 2. Some yellow sapphires $(23.78 \mathrm{ct}$, left $)$ and all golden beryls (heliodor, $9.94 \mathrm{ct}$, right) owe their color to $\mathrm{O}^{2-} \rightarrow \mathrm{Fe}^{3+}$ charge transfer. Photo by Shane McClure.

about the same energy - that is, the same region of the spectrum-in corundum (Tippins, 1970). Therefore, it contributes a similar strong yelloworange color to sapphires, despite the fact that the details of the coordination environment are quite different.for the isolated ion in these two minerals (in contrast, see Fritsch and Rossman, 1987, for the difference in color produced by chromium $\left[\mathrm{Cr}^{3+}\right]$ in beryl [emerald] and corundum (ruby]).

The center of the oxygen $\rightarrow$ metal ion chargetransfer absorption band moves from the ultraviolet toward the visible region as the positive charge of the central metal ion increases. $\mathrm{O}^{2-} \rightarrow \mathrm{Fe}^{2+}$ charge transfer is centered well into the ultraviolet and has minimal effect on color, whereas $\mathrm{O}^{2-} \rightarrow$ $\mathrm{Fe}^{3}+$ charge transfer is centered at the edge of the ultraviolet, and extends into the visible region, generally causing yellow to brown hues. Finally, $\mathrm{O}^{2-} \rightarrow \mathrm{Fe}^{4+}$ transitions absorb light in the middle of the visible region, giving amethyst, for example, its purple color (Cox, 1977).

Even ions that are not likely to generate color by themselves can do so with oxygen $\rightarrow$ metal charge transfer. For instance, the chromate group $\left|\mathrm{Cr}^{6}+\mathrm{O}_{4}\right|$ gives the mineral crocoite its bright orange-red color (see figure 1). The oxygen ions transfer some of their electrons to the chromium ion in such a way that transitions absorbing in the near ultraviolet and in part of the violet and blue are possible (Loeffler and Burns, 1976).

Transitions associated with a single metal ion have a much lower probability of occurring than do charge-transfer transitions. In the case of $\mathrm{Fe}^{3+}$, the absorption resulting from one charge-transfer transition is 100 to 1,000 times stronger than that resulting from an internal transition confined to the isolated ion (Mattson and Rossman, 1987a, 1987b). Consequently, charge-transfer colors are more intense than those caused by dispersed metal ions. Of course, the intensity of the color also depends on the extent to which the charge-transfer absorption occurs in the visible portion of the spectrum.

When an Electron Visits Its Next-Nearest Neighbor: Intervalence Charge Transfer. In some cases, an electron can travel further than one ion away, such that two metal ions separated by an oxygen atom can actually exchange electrons, too. This process can strongly influence the color of a gem. When such a transition takes place between two different oxidation states (e.g., $\mathrm{Fe}^{2+}$ and $\mathrm{Fe}^{3+}$ ), it is called an intervalence charge-transfer (IVCT) transition.

Because of the natural abundance of iron, charge transfer is commonly observed between $\mathrm{Fe}^{2+}$ and $\mathrm{Fe}^{3+}$. A popular gemstone colored by this type of IVCT is darker blue aquamarine, like the material from Coronel Murta (Brazil) and Tongafeno (Malagasy Republic). As we have seen already, the presence of $\mathrm{Fe}^{3+}$ induces the absorption of at least part of the violet, through $\mathrm{O}^{2-} \rightarrow$ $\mathrm{Fe}^{3+}$ charge transfer. But when $\mathrm{Fe}^{2+}$ is also present in the adjacent site, the $\mathrm{Fe}^{2+} \rightarrow \mathrm{Fe}^{3+}$ IVCT strongly absorbs in the red end of the spectrum/Goldman et al., 19781. As the violet is already suppressed, this leaves a transmission window in the blue.

When there is much more $\mathrm{Fe}^{3+}$ than $\mathrm{Fe}^{2+}$, the $\mathrm{O}^{2-} \rightarrow \mathrm{Fe}^{3+}$ charge transfer also absorbs part of the blue and results in a more greenish color. Heat treatment in a reducing atmosphere is used to change part of the $\mathrm{Fe}^{3+}$ to $\mathrm{Fe}^{2+}$ (Nassau, 1984). This moves the transmission window back into the blue, and produces a more saleable stone.

Intervalence charge transfers also occur between metal ions of different chemical elements. Such is the case for the $\mathrm{Fe}^{2+} \rightarrow \mathrm{Ti}^{4+}$ charge transfer that gives sapphire its blue color (figure 3). The heat treatment of near-colorless "geuda" sapphires produces blue stones because naturally occurring inclusions of rutile and spinel in the corundum dissolve at high temperatures. Fe and Ti from the inclusions are released and, through random diffusion, form pairs of $\mathrm{Fe}^{2+}$ and $\mathrm{Ti}^{4+}$ ions which interact through $\mathrm{Fe}^{2+} \rightarrow \mathrm{Ti}^{4}+$ IVCT to yield the blue coloration (Harder and Schneider, 1986). The 
As one can appreciate from the former examples, charge-transfer processes generally create a strong pleochroism. To understand why the absorption is more intense in one direction than the other, it is necessary to know the exact location of the ions involved (see, e.g., figures 4 and 5). For many gem materials this is still under investigation.

Ion Pair Transitions. $\mathrm{Fe}^{3+}-\mathrm{Fe}^{3+}$ pair transitions are mentioned by Ferguson and Fielding (1971) to account for the color of some yellow sapphires. This type of cause of color has also been used to explain the hue of some red dravites (Mattson and Rossman, 1984), but the absorption is so efficient that any cut stone would be very dark. These absorptions are situated between 300 and $500 \mathrm{~nm}$, where they absorb the blue end of the spectrum and generate yellow to red colors. In contrast to intervalence charge transfer, these are not single transitions involving only one electron: They arise from a transition that occurs simultaneously in both $\mathrm{Fe}^{3+}$ ions. In some cases, their energy is a sum of the energy of two isolated metal-ion transitions; this explains their relatively high-energy position (near-ultraviolet and blue end of the visible spectrum). It must be emphasized that such transitions are very strongly oriented along the $\mathrm{Fe}^{3+}-\mathrm{O}-\mathrm{Fe}^{3+}$ bonds; as a result, they induce pleochroism. They are important in the heat treatment of sapphire. Whereas high-temperature treatment dissolves Fe and $\mathrm{Ti}$ to produce blue sapphire, treatment at less extreme temperatures can allow $\mathrm{Fe}^{3+}$ ions to diffuse together to form $\mathrm{Fe}^{3+}-\mathrm{Fe}^{3+}$ pairs which contribute to the color of some yellow sapphires.

Processes Not Involving Metal Ions. Although not commonly seen in gem materials, the colors of some minerals do not involve metal ions. A classic example is lazurite /the main component of lapis lazuli). This mineral contains sulphur atoms in its chemical formula. When the sulphur atoms are grouped in the form of the $\left.\mid \mathrm{S}_{3}\right)^{-}$molecule, transitions among the atoms in this grouping produce the deep blue color (see Loeffler and Burns, 1976).

For organic gem materials, such as amber and pearls, delocalization of electrons is the most common cause of color (Nassau, 1975). Electrons can be delocalized (i.e., spread) over several atoms or over a whole molecule (a molecule is a group of atoms held together by chemical forces) through shared orbitals in which the electron travels. These 


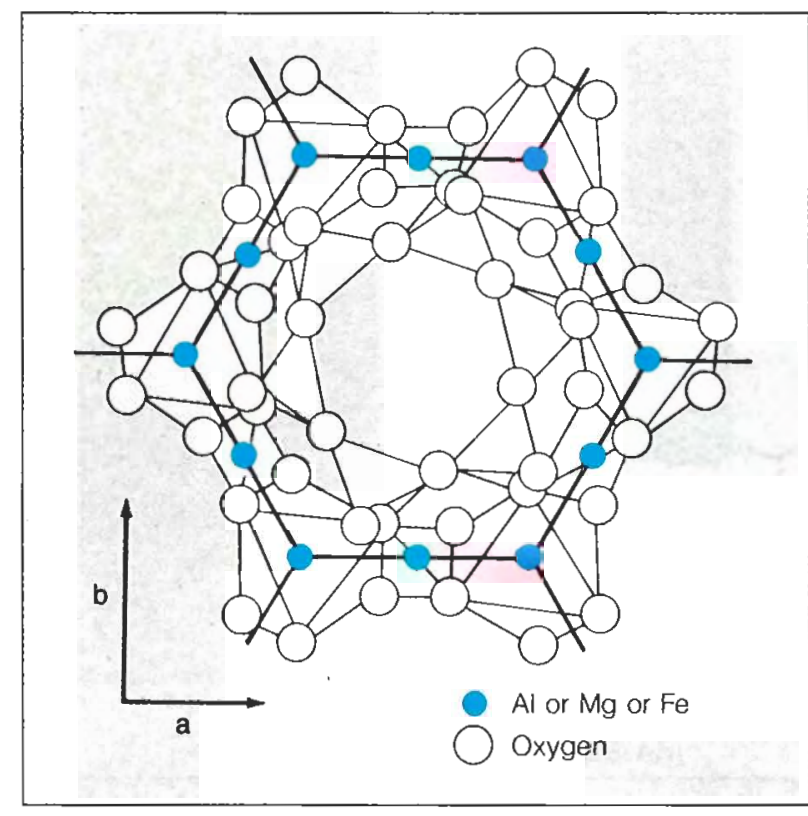

A

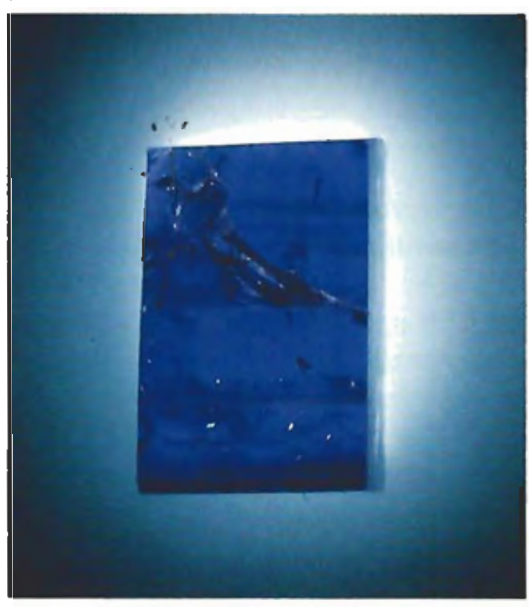

B

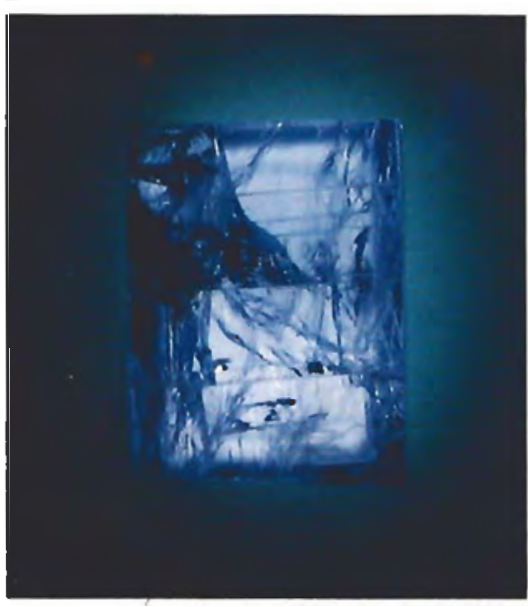

Figure 4. This diagram shows the structure of cordierite (iolite), viewed down the c-axis, as it relates to pleochro ism. Iron ions substitute for Al or $\mathrm{Mg}$ atoms, so the intervalence charge transfer will occur in the three directions in which the $\mathrm{Al}$ and $\mathrm{Mg}$ atoms are aligned (heavy lines). One of those directions is strictly parallel to the a-axis, so light vibrating in this direction will be strongly absorbed, producing a very intense blue (A). Light vibrating in the other two directions will induce intervalence charge transfers at about $30^{\circ}$ to the b-axis, thereby resulting in a lighter blue (B). There is no IVCT parallel to the c-axis (perpendicular to the plane of the figure), so no charge transfer for light vibrating in that direction is observed; the light yellow color is due to isolated $\mathrm{Fe}^{3+}$ (C). After Faye et al., 1968. The three different colors are easily seen on this specimen, photographed with light polarized parallel to the a (photo A), $b$ (photo B) and c (photo C) axes, respectively. Photos by Shane McClure.

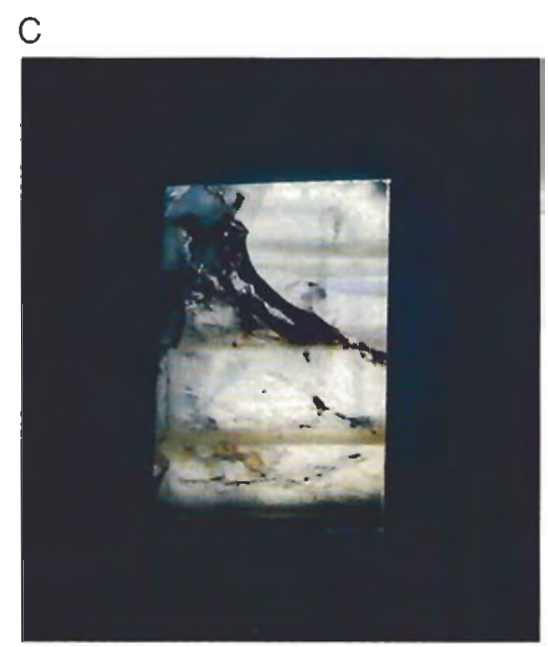

orbitals are called "molecular orbitals." Transitions can occur between molecular orbitals and absorb visible light, thereby causing color.

"Honey" to yellow tones of amber are the result of this delocalization (figure 6), as are the delicate pink to red colors of coral (figure 7) and some conch "pearls." The vast majority of the dyes used to enhance the color of gemstones also owe their effectiveness to molecular orbital transitions (Griffiths, 1981). Sometimes organic components give rise to a strong fluorescence, which provides a useful way of identifying foreign organic products such as some oil in emerald, dye in jadeite, and glues.
Various examples of charge-transfer colorations in gem materials are given in table 1. Again, one should remember that multiple coloring processes can occur simultaneously in a given gem material, and distinctly different processes can produce very similar colors. If the color of a particular stone is caused by dispersed metal ions, establishing the origin of color is usually a straightforward process. However, in cases where the origin of color involves charge transfer or, more generally, multiple atoms, it is often much more difficult to rigorously assess the cause of color, for a number of reasons explained by Mattson and Rossman (1987b). 

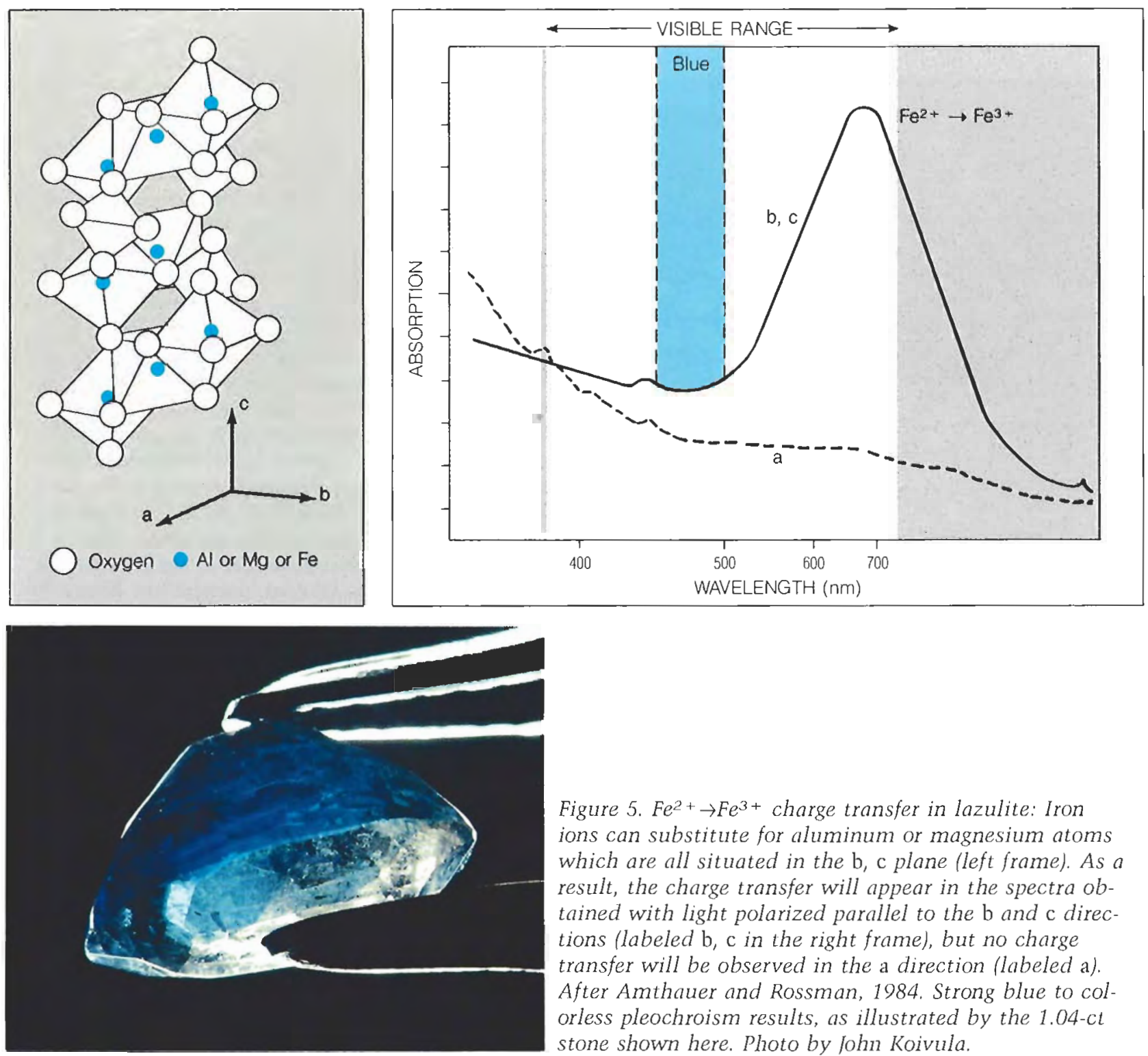

Figure 5. $\mathrm{Fe}^{2+} \rightarrow \mathrm{Fe}^{3+}$ charge transfer in lazulite: Iron ions can substitute for aluminum or magnesium atoms which are all situated in the $\mathrm{b}$, c plane (left frame). As a result, the charge transfer will appear in the spectra obtained with light polarized parallel to the $\mathrm{b}$ and $\mathrm{c}$ directions (labeled $\mathrm{b}, \mathrm{c}$ in the right frame), but no charge transfer will be observed in the a direction (labeled a). After Amthauer and Rossman, 1984. Strong blue to colorless pleochroism results, as illustrated by the 1.04-ct stone shown here. Photo by John Koivula.

\section{COLOR CENTERS: \\ HOW IMPERFECTIONS LEAD TO BEAUTIFUL COLORS}

Many colors in gemstones are the result of exposure to high-energy radiation. This can happen in nature as a result of the widespread occurrence of low concentrations of naturally radioactive isotopes of $\mathrm{U}, \mathrm{Th}$, and $\mathrm{K}$. It can alsc occur through artificial irradiation by means of a wide variety of laboratory and industrial technologies. Radiation can (1) change the oxidation state of metal ions and (2) interact with "defects" in the crystal. These defects may be, for example, missing atoms (vacancies) or additional atoms (interstitials). Also, electrons extracted by irradiation somewhere else in the crystal can be put into preexisting growth or mechanical defects. This is sometimes poetically called "decorating a defect." These defects could, from the physical point of view, be considered "pseudo-atoms," inasmuch as they are usually the size of one or a few atoms. Color center is the generic term for a defect that causes light absorption (even if it is not in the visible range), particularly one that is affected by irradiation. Kittel (1980) gives a more systematic and theoretical approach to color centers, for those readers interested in greater detail.

The concept of color center is best explained through some typical examples. A vacancy type of color center means that an atom that is usually 


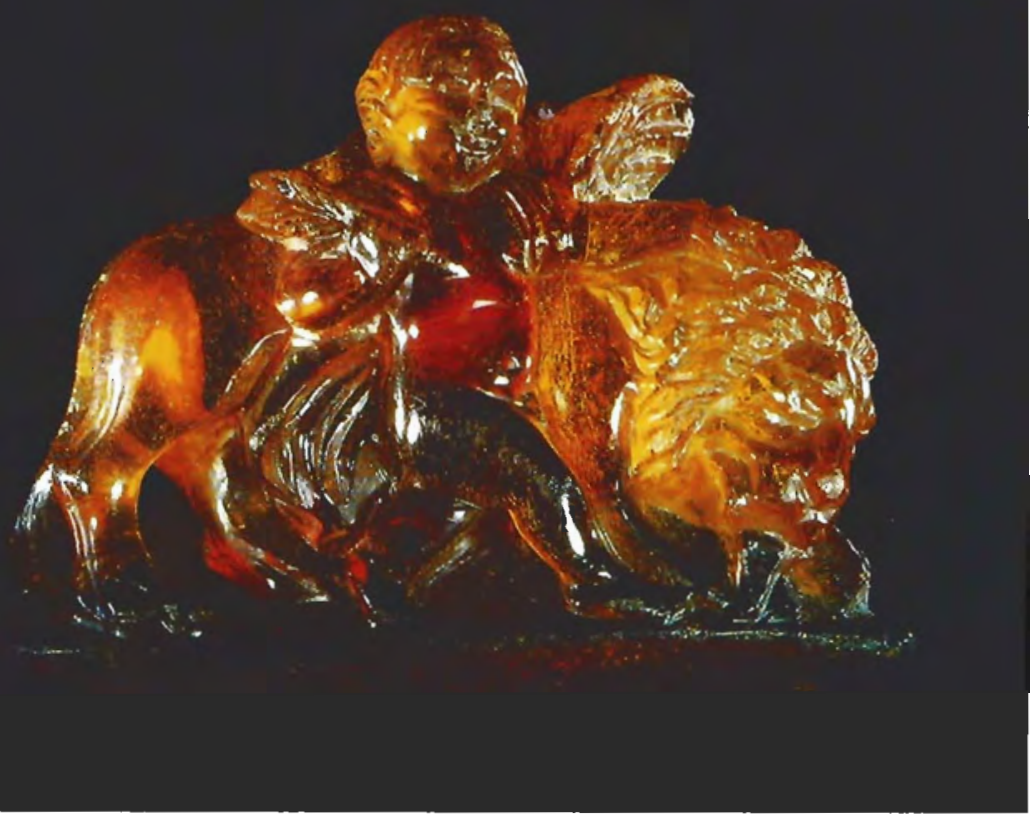

Figure 6. Baltic amber, here carved in the form of Eros with a lion, is colored by electron delocalization over the large organic molecules that form amber. This 4.6$\mathrm{cm}$-long carving, which dates from the first century A.D., is from the De Bry Collection, Paris. Photo (C) Nelly Bariand.

Figure 7. The coral from which this $32.5-\mathrm{cm}$-wide piece was carved comes from the coral beds of Taiwan. The red hue is due to small amounts of an organic molecule from the carotenoid family. From the collection of Jack and Elaine Greenspan; photo $(\mathcal{C}$ Harold \&) Erica Van Pelt.

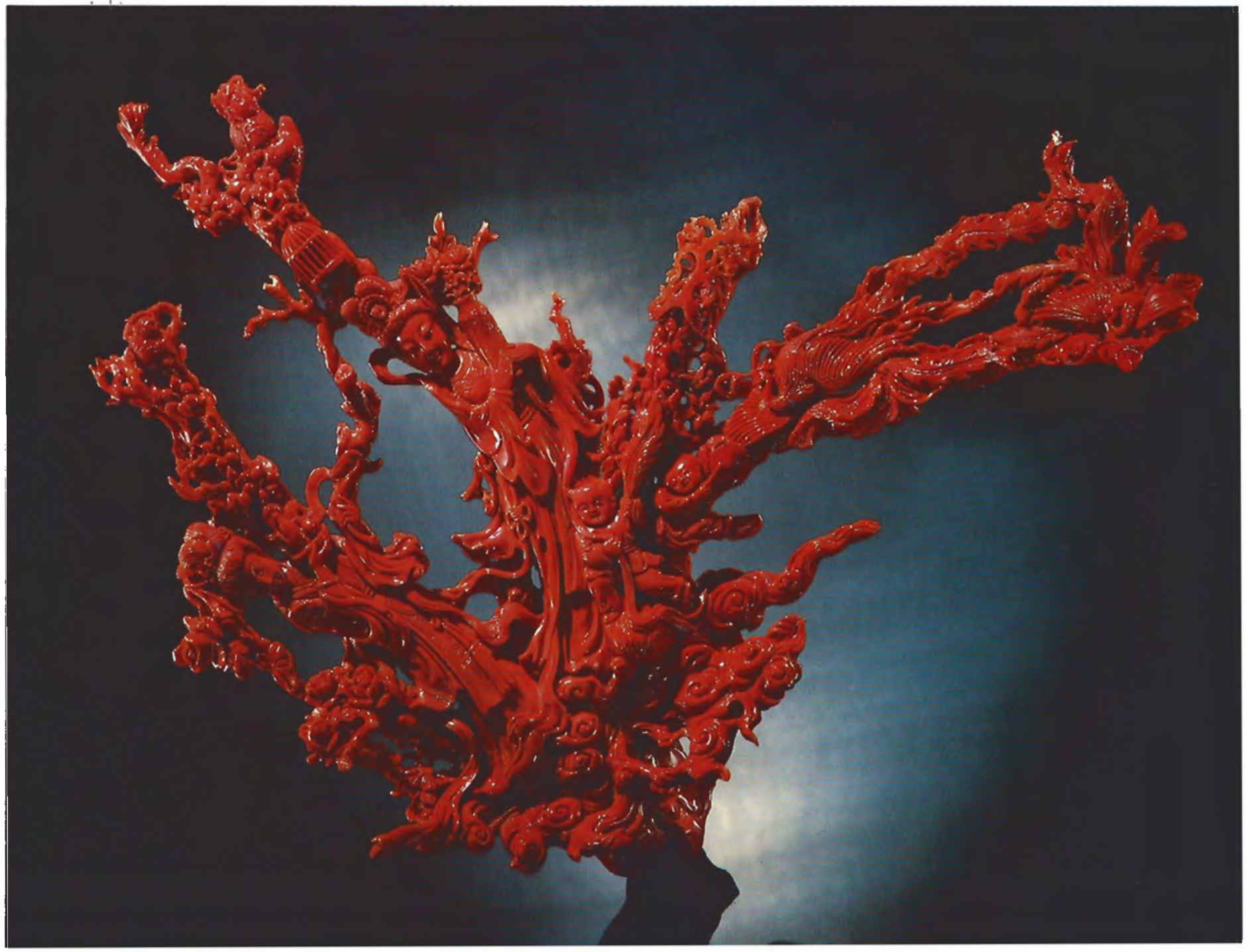


TABLE 1. Color-producing processes involving multiple atoms and examples of the colors they cause in various gem materials.

\begin{tabular}{|c|c|}
\hline Process & $\begin{array}{l}\text { Color and } \\
\text { gem material }\end{array}$ \\
\hline \multicolumn{2}{|l|}{ Charge transfer } \\
\hline \multicolumn{2}{|c|}{ Oxygen $\rightarrow$ metal charge transfer } \\
\hline $\mathrm{O}^{2-} \rightarrow \mathrm{Fe}^{3+}$ & $\begin{array}{l}\text { Yellow to brown: beryl/heliodor (Wood and } \\
\text { Nassau, 1968), corundum (Schmetzer et al., } \\
\text { 1982), quartz/citrine, burned amethyst (Bal- } \\
\text { itsky and Balitskaya, 1986), sinhalite (Farrell } \\
\text { and Newnham, 1965) }\end{array}$ \\
\hline $\mathrm{O}^{2-} \rightarrow \mathrm{Fe}^{4+}$ & Purple: quartz/amethyst (Cox, 1977) \\
\hline $\mathrm{O}^{2-} \rightarrow \mathrm{Cr}^{6+}$ & $\begin{array}{l}\text { Yellow to red: crocoite (Loeffler and Burns, } \\
\text { 1976) }\end{array}$ \\
\hline \multicolumn{2}{|c|}{ Intervalence charge transfer } \\
\hline $\mathrm{Fe}^{2+}-\mathrm{O}-\mathrm{Fe}^{3+}$ & $\begin{array}{l}\text { Violet: "lavender" jadeite (Rossman, 1974) } \\
\text { Blue: beryl/aquamarine (Goldman et al., } \\
\text { 1978), cordierite/iolite (Faye et al., 1968), } \\
\text { lazulite (Amthauer and Rossman, 1984), am- } \\
\text { phibole/glaucophane (Smith and Strens, } \\
\text { 1976), kyanite (Parkin et al., 1977), euclase } \\
\text { (Mattson and Rossman, 1987b) }\end{array}$ \\
\hline $\mathrm{Fe}^{2+}-\mathrm{O}-\mathrm{Ti}^{4+}$ & $\begin{array}{l}\text { Blue: corundum (Smith and Strens, 1976), } \\
\text { kyanite (Parkin et al., 1977) } \\
\text { Brown: dravite (Smith, 1977), andalusite } \\
\text { (Smith, 1977) } \\
\text { Yellow to black: titanian andradite/melanite } \\
\text { (not fully proved, Moore and White, 1971) }\end{array}$ \\
\hline $\mathrm{Mn}^{2+}-\mathrm{O}-\mathrm{Ti}^{4+}$ & $\begin{array}{l}\text { Greenish yellow: tourmaline (Rossman and } \\
\text { Mattson, 1986) }\end{array}$ \\
\hline \multicolumn{2}{|c|}{ Processes not involving metal ions } \\
\hline $\mathbf{S}_{3}^{-}$ & $\begin{array}{l}\text { Blue lazurite/lapis lazuli (see Loeffler and } \\
\text { Burns, 1976) }\end{array}$ \\
\hline $\begin{array}{l}\text { Various organic } \\
\text { compounds }\end{array}$ & $\begin{array}{l}\text { Yellow to brown: amber and copal, tortoise } \\
\text { shell (Nassau, 1975) }\end{array}$ \\
\hline Porphyrins & $\begin{array}{l}\text { Green and pink: oyster pearls (Fox et al., } \\
\text { 1983) }\end{array}$ \\
\hline Carotenoïds & $\begin{array}{l}\text { Pink to red: conch "pearl," coral (Délé- } \\
\text { Dubois and Merlin, 1981) }\end{array}$ \\
\hline "Chromophores" & Any color: organic dyes (Griffiths, 1981) \\
\hline
\end{tabular}

present in a particular type of crystal has been removed by irradiation (see figure 8). This kind of defect is responsible for the color of most green diamonds, which have been exposed to radiation that is strong enough to remove carbon atoms from their original positions. This can happen either naturally or in the laboratory. A neutral carbon vacancy (i.e., without electrons in it), called the GRI center, is created and absorption occurs in the red and orange (Collins, 1982). This leaves a transmission window either in the blue (if there is no absorption in the violet-blue, as in nonconductive, treated blue diamonds) or, more commonly, in the green.

In most cases, instead of dislocating an entire atom, irradiation expels an electron from its orbital. This is the explanation for the origin of color in two common varieties of quartz: smoky quartz and amethyst. In all smoky quartz crystals, aluminum $\left(\mathrm{Al}^{3+}\right)$ replaces a small part of the silicon $\left(\mathrm{Si}^{4+}\right)$. The presence of the aluminum impurity is not, in and of itself, enough to cause the color; the crystal has to be irradiated. Natural irradiation, over geologic time, can remove an electron from an oxygen atom adjacent to an aluminum ion (see figure 9), creating an intense absorption in the ultraviolet that extends into the visible range and induces the typical smoky color. Quartz will become completely black if the radiation is intense and the crystal contains enough aluminum. On heating, the smoky color leaves and the quartz returns to its original colorless state.

In amethyst, iron is the initial impurity. $\mathrm{Fe}^{3+}$ occupying the silicon site in quartz is changed by irradiation into $\mathrm{Fe}^{4+}$, an uncommon valence state for iron (Cox, 1977). This oxidation state results from natural irradiation in the case of natural amethyst and from laboratory irradiation in the case of synthetic amethyst. The characteristic deep purple transmission results from absorption due to $\mathrm{O}^{2+} \rightarrow \mathrm{Fe}^{4+}$ charge transfer (see above), which is centered in the yellow-green.

$\mathrm{Fe}$ and $\mathrm{Al}$ are common impurities in quartz. Less common foreign molecules can also produce some spectacular colors in certain minerals. For example, the carbonate group $\left(\mathrm{CO}_{3}\right)^{2-}$ can be incorporated into the channels of the beryl structure during crystal growth. Under the influence of irradiation (usually natural but also possible in the laboratory if the precursor is there), this molecule loses an electron and becomes $\left(\mathrm{CO}_{3}\right)^{-}$. The remaining extra electron on this molecule induces a broad absorption from the red to the green / see figure 10). This produces the attractive sapphireblue color of the Maxixe-type beryl (Edgar and Vance, 1977). Interestingly, the sapphire-blue beryl originally found at the Maxixe mine in Minas Gerais, Brazil, is colored by a similar but different defect, the $\mathrm{NO}_{3}$ group, which results from the irradiation of a nitrate impurity $\left(\mathrm{NO}_{3}\right)^{-}(\mathrm{An}$ dersson, 1979). Unfortunately, like many other gemstones in which the color originates in color centers, Maxixe and Maxixe-type beryl fade when exposed to daylight. 

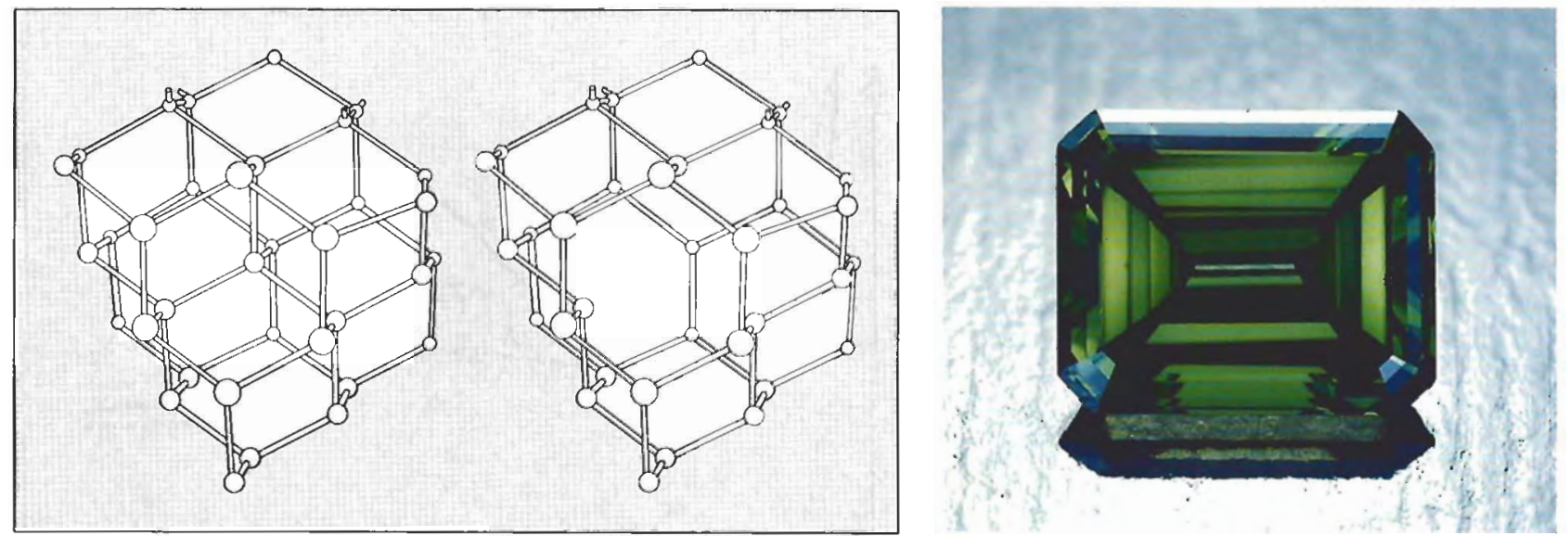

Figure 8. Strong radiation moves an atom away from its normal position (left) to produce a neutral carbon vacancy (right) in diamond. From Bursill and Glaisher, 1985. This very simple color center, called GR1 (general radiation 1) induces green color in diamond, as seen in the 0.40-ct treated green stone on the right. Diamond courtesy of Theodore and Irwin Moed, Inc.; photo 0 Tino Hammid.

One of the interesting features of the $\left(\mathrm{CO}_{3}\right)^{-}$ defect in beryl is the very large breadth of its absorption range. In fact, in addition to the first sharp absorption, the $\left(\mathrm{CO}_{3}\right)$ - defect is represented

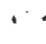

Figure 9. The color center responsible for the coloration of smoky quartz is more complex than that which colors green diamond. Irradia tion removes an electron from an oxygen atom that is bonded to an aluminum atom, substituting for silicon.

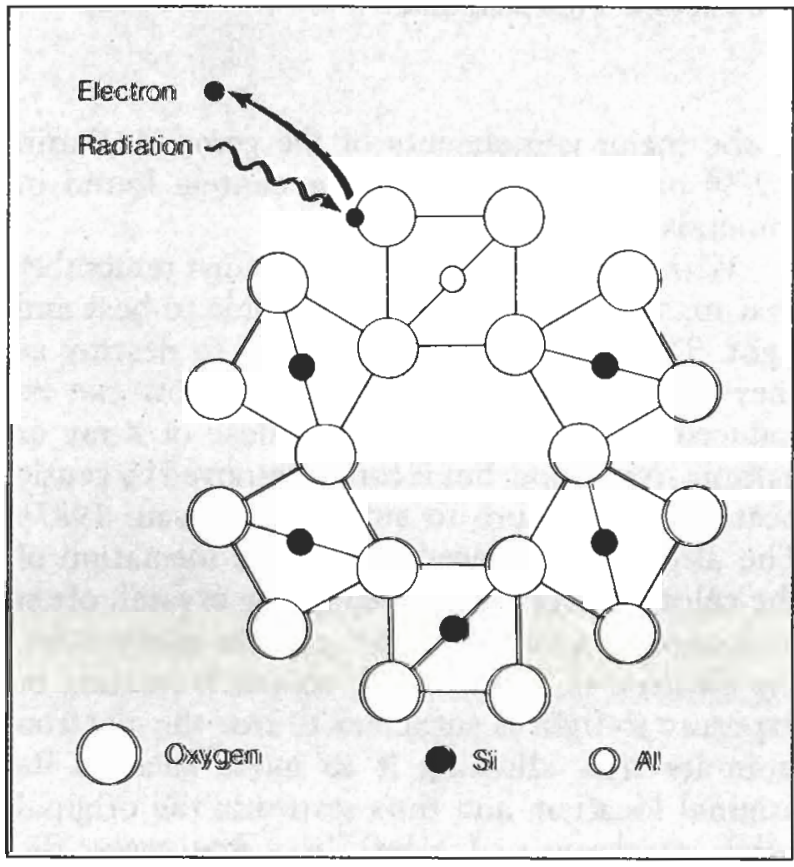

by a group of bands that are spaced in a relatively regular way with decreasing intensity for shorter wavelengths (again, see figure 10). These are due to a strong coupling between the absorbing center and the vibrations of the molecule. Such an absorption system is called vibronic. The broad absorption feature is primarily responsible for the coloration; the absorption under the sharp peak absorbs so little light that it will hardly influence the color. Interestingly, this type of absorption system is responsible for most diamond colorations (Collins, 1982): yellow from the N2 and N3 centers (Cape lines), orange from the $\mathrm{H} 3$ center $(503 \mathrm{~nm}$ and related bands), green from the GRI center (again see figure 81, and other colors from combinations of these.

Color centers can be more complicated than just a vacancy or a foreign molecule, and often involve a defect in the crystal plus an impurity adjacent to it. Some fluorites $\left(\mathrm{CaF}_{2}\right)$ are light blue because they contain an yttrium $\left(\mathrm{Y}^{3+}\right)$ ion substituting for the calcium near a fluorine vacancy, which is populated by two electrons. This complex center absorbs in the violet and the yellow-green and so gives a blue hue (Bill and Calas, 1978).

Another example of a color center involving multiple components is the blue to green variety of microcline feldspar (amazonite). Hofmeister and Rossman (1985) attributed the color to $\mathrm{Pb}^{2}+$ in the crystal structure substituting for two potassium $\left(\mathrm{K}^{+}\right)$ions. Under the action of natural irradiation, the lead is oxidized to $\mathrm{Pb}^{3+}$. This oxidation only occurs if water molecules are bound to the struc- 

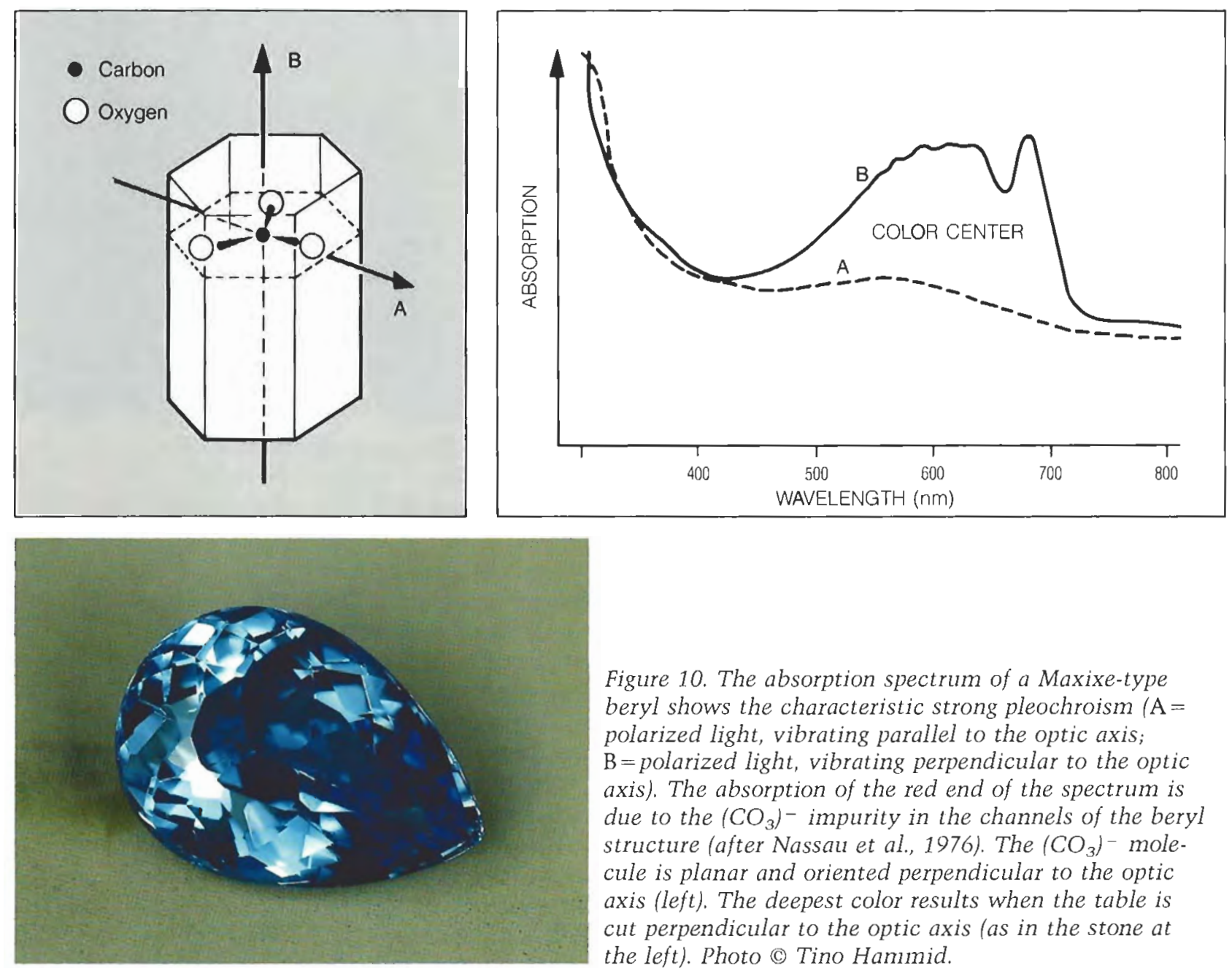

Figure 10. The absorption spectrum of a Maxixe-type beryl shows the characteristic strong pleochroism $(\mathrm{A}=$ polarized light, vibrating parallel to the optic axis; $\mathrm{B}=$ polarized light, vibrating perpendicular to the optic axis). The absorption of the red end of the spectrum is due to the $\left(\mathrm{CO}_{3}\right)^{-}$impurity in the channels of the beryl structure (after Nassaut et al., 1976). The $\left(\mathrm{CO}_{3}\right)^{-}$molecule is planar and oriented perpendicular to the optic axis (left). The deepest color results when the table is cut perpendicular to the optic axis (as in the stone at the left). Photo ()$^{\text {Tino Hammid. }}$

ture in the vicinity of lead. This particular combination of impurities generates the blue to green color. This example also demonstrates the influence of water content on the susceptibility of a mineral to coloration by irradiation. In some cases, such as amazonite, water helps create color; in others, such as smoky quartz and amethyst, it prevents the coloration (Aines and Rossman, 1986).

Table 2 provides some idea of the wide variety of color centers in gem materials. Sophisticated techniques are usually required for their identification. The details of the color centers in even common stones, such as blue topaz (see figure 11), are still under debate (Schmetzer, 1987). Many of the color centers that result from irradiation require the presence of an impurity, but they also can be due solely to the effect of the irradiation on one of the major components of the gem. Marfunin (1979) provides a list of color centers found in minerals and gem materials.

With regard to treatment, one must remember that many color centers are unstable to heat and light. They are sometimes as easy to destroy as they are to induce. For example, yellow can be induced in corundum by a low dose of X-ray or gamma irradiation, but it can be removed by gentle heating or exposure to sunlight (Nassau, 1987). The electrons displaced during the formation of the color centers are trapped in the crystal, often by a nearby cation $\left(\mathrm{H}^{+}, \mathrm{Na}^{+}\right.$, etc. $)$. In many cases, the electron is weakly held, so gentle heating or exposure to light is sufficient to free the electron from its trap, allowing it to move back to its original location, and thus restoring the original color (or absence of color). In a few cases, the 
TABLE 2. Examples of gem materials colored by color centers, with an indication of the origin of color. ${ }^{a}$

\begin{tabular}{|c|c|c|}
\hline Gem material & & Origin of color \\
\hline Diamond & & $\begin{array}{l}\text { Green: neutral carbon vacancy/GR1 center } \\
\text { (Collins, 1982) } \\
\text { Yellow: aggregate of } 3 \text { nitrogen atoms/N3 } \\
\text { center (Collins, 1982) } \\
\text { Orange: vacancy trapped at nitrogen aggre- } \\
\text { gates/H3 and } \mathrm{H} 4 \text { centers (Collins, 1982) }\end{array}$ \\
\hline Quartz & & $\begin{array}{l}\text { Smoky: } \mathrm{Al}^{3}+\text { impurity + irradiation (see Part- } \\
\text { low and Cohen, 1986) } \\
\text { Yellow: } \mathrm{Al}^{3+} \text {-related color centers (Sam- } \\
\text { oilovich et al., 1969) } \\
\text { Purple: } \mathrm{Fe}^{3}+\text { impurity + irradiation } \rightarrow \mathrm{Fe}^{4+} \\
\text { (Balitsky and Balitskaya, 1986) }\end{array}$ \\
\hline Corundum & & $\begin{array}{l}\text { Yellow: unstable color centers of unknown } \\
\text { structure (Schiffman, 1981; Nassau, 1987) }\end{array}$ \\
\hline Topaz & & $\begin{array}{l}\text { Blue: color centers of unknown structure } \\
\text { (Schmetzer, 1986) } \\
\text { Yellow: color center of unknown structure } \\
\text { (Petrov, 1977) } \\
\text { Reddish brown: "red" and "yellow" color cen- } \\
\text { ters of unknown structure (Petrov, 1977) }\end{array}$ \\
\hline Tourmaline & & Red: $M n^{3}+$ due to irradiation (Manning, 1973) \\
\hline Feldspar & & $\begin{array}{l}\text { Blue to green: color center involving } \mathrm{Pb} \\
\text { (Hofmeister and Rossman, 1985, 1986) }\end{array}$ \\
\hline Scapolite & $\because$ & $\begin{array}{l}\text { Violet: color centers related to radicals in the } \\
\text { channels of the structure (Marfunin, 1979) }\end{array}$ \\
\hline Beryl & . & $\begin{array}{l}\text { Blue (Maxixe-type or Maxixe): } \mathrm{CO}_{3} \text { or } \mathrm{NO}_{3} \\
\text { group due to irradiation (Andersson, 1979) }\end{array}$ \\
\hline Spodumene & - & $\begin{array}{l}\text { Green: unstable } \mathrm{Mn}^{4}+\text { due to irradiation } \\
\text { (Cohen and Janezic, 1983) } \\
\text { Yellow: color center of unknown structure } \\
\text { (Rossman and Qiu, 1982) }\end{array}$ \\
\hline Fluorite & & $\begin{array}{l}\text { Blue: } \mathrm{Y}_{3}+\text { fluorine vacancy }+2 \text { electrons } \\
\text { Pink: } \mathrm{YO}_{2} \text { center }\left(\mathrm{Y}^{3}+\mathrm{O}_{2}^{3-}\right) \\
\text { Yellow: } \mathrm{O}_{3}^{-} \text {center }=\mathrm{O}_{2} \text { substituting for fluorine } \\
\text { (Bill and Calas, } 1978)\end{array}$ \\
\hline Sodalite & & $\begin{array}{l}\text { Blue: interstitial oxygen ion } \mathrm{O}^{-} \text {near aluminum } \\
\text { or silicon (Pizani et al., 1985) } \\
\text { Pink: unstable electron substituting for } \mathrm{Cl}^{-} \text {in a } \\
\text { tetrahedron of } \mathrm{Na}+\text { ions (Pizani et al., 1985) }\end{array}$ \\
\hline \multicolumn{3}{|c|}{$\begin{array}{l}\text { a A given color in a specific gem material can be due to different causes, } \\
\text { Consequently, not all yellow sapphires are, for example, colored by a color } \\
\text { center (see table 1). }\end{array}$} \\
\hline
\end{tabular}

electron is tightly held, so the color is stable (e.g., red tourmaline).

In some instances, irradiation creates several centers at the same time. For example, in the commercial treatment of blue topaz, both blue and brown centers may be generated in the initial irradiation. Gentle heating is then used to remove the brown component (Nassau, 1985). Another possibility is that treatment does not create directly the desired color center, and that heating is

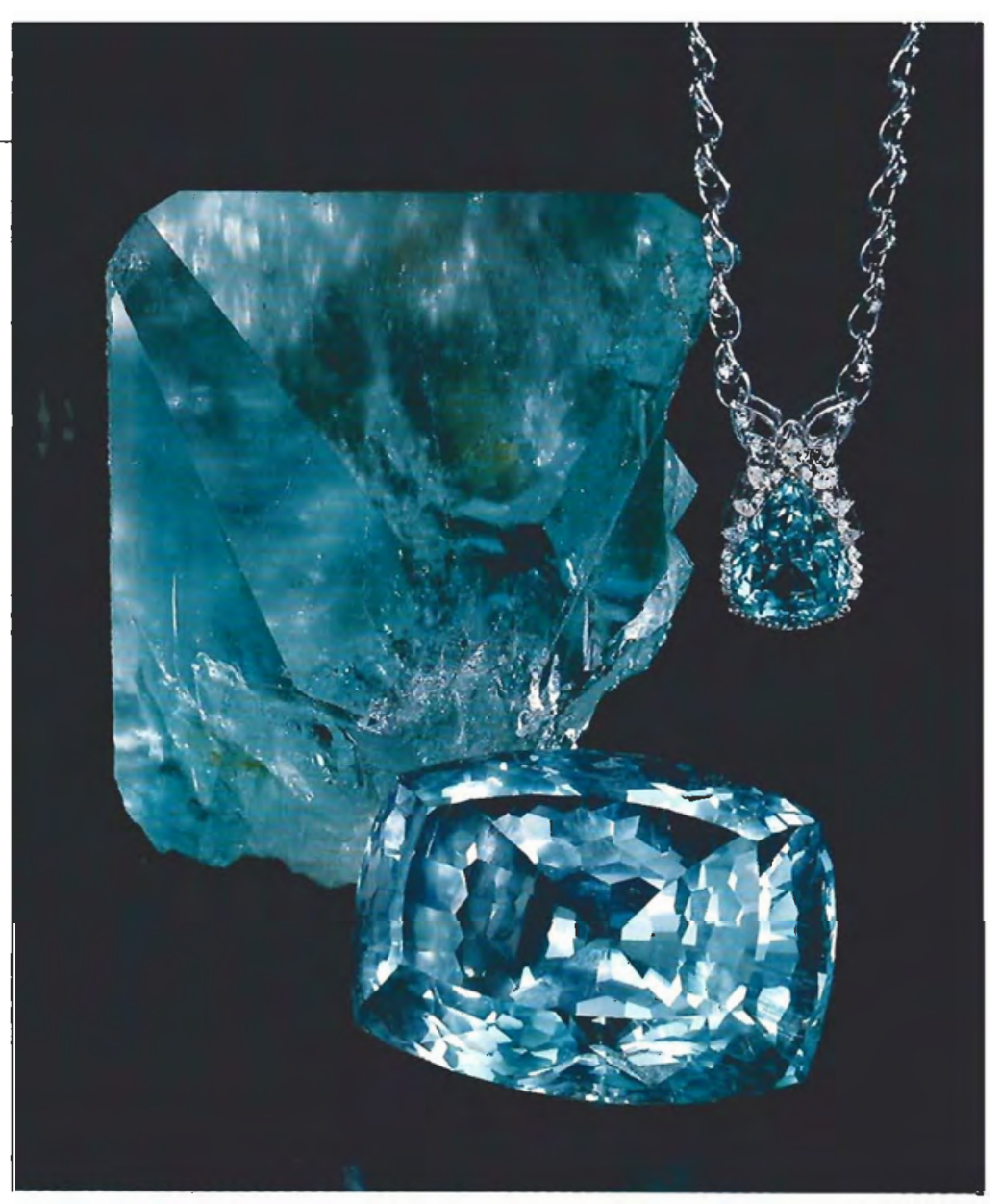

Figure 11. This 17-cm-high crystal of blue topaz from Virgem de Lapa and the 182-ct faceted topaz from Minas Gerais are both of natural color. The pear-shaped blue topaz in the pendant owes its color to artificial irradiation and subsequent annealing. The structure of the color centers in both natural and treated blue topaz is still under investigation. Stones and jewelry courtesy of The Collector, La Jolla and Fallbrook, CA; photo (C) Harold (4) Erica Van Pelt.

required to bring the necessary ingredients together. Such is the case for many treated colored diamonds, in which vacancies move during annealing to meet one of the forms of nitrogen impurities (Collins, 1982).

\section{CONCLUSION}

We have now reviewed the three most common causes of color in gem materials: dispersed metal ions (Fritsch and Rossman, 1987), charge transfers and other processes that involve multiple ions, and color centers. The last article of this series will deal with types of coloration that are less often seen in gems, such as those that result from physical phenomena (as in opal) or from semiconductor-like properties (as in natural blue diamond). 


\section{REFERENCES}

Aines R.D., Rossman G.R. (1986) Relationships between radiation damage and trace water in zircon, quartz, and topaz. American Mineralogist, Vol. 71, pp. 1186-1193.

Amthauer G., Rossman G.R. (1984) Mixed valence of iron in minerals with cation clusters. Physics and Chemistry of Minerals, Vol. 11, pp. 37-51.

Andersson L.O. (1979) The difference between Maxixe beryl and Maxixe-type beryl: An electron paramagnetic resonance investigation. Journal of Gemmology, Vol. 16, No. 5, pp. 313-317.

Balitsky V.S., Balitskaya O.V. (1986) The amethyst-citrine dichromatism in quartz and its origin. Physics and Chemistry of Minerals, Vol. 13, pp. 415-421.

Bill H., Calas G. (1978) Color centers, associated rare-earth ions and the origin of coloration in natural fluorites. Physics and Chemistry of Minerals, Vol. 3, pp. 117-131.

Burns R.G. (1970) Mineralogical applications of crystal field theory. Cambridge Earth Science series, Cambridge University Press, London.

Bursill L.A., Glaisher R.W. (1985) Aggregation and dissolution of small and extended defect structures in type la diamond. American Mineralogist, Vol. 70, pp. 608-618.

Cohen A.I., Janezic G.G. (1983) The crystal-field spectra of the $3 \mathrm{~d}^{3}, \mathrm{Cr}^{3+}$ and $\mathrm{Mn}^{4+}$ in green spodumenes. In The Signifcance of Trace Elements in Solving Petrogenetic Problems and Controversies, Theophrastus Publications, Athens, Greece.

Collins A.T. (1982) Colour centres in diamond. Journal of Gemmology, Vol. 18, No. 1, pp. 37-75.

Cox R.T. (1977) Optical absorption of the $\mathrm{d}^{4}$ ion $\mathrm{Fe}^{4+}$ in pleochroic amethyst quartz. Journal of Physics, Vol. C10, pp. $4631-4643$

Délé-Dubois M.-L., Merlin J.-C. \{1981\} Étude par spectroscopie Raman de la pigmentation du squelette calcaire du corail. Revue de Gemmologie a.f.g., Vol. 68, pp. 10-13.

Edgar A., Vance E.R. (1977) Electron paramagnetic resonance, optical absorption, and magnetic circular dichroism studies of the $\left(\mathrm{CO}_{3}\right)^{-}$molecular ion in irradiated natural beryl. Physics and Chemistry of Minerals, Vol. 1, pp. $165-178$.

Farrell E.F., Newnham R.E. (1965) Crystal-field spectra of chrysoberyl, alexandrite, peridot, and sinhalite. American Mineralogist, Vol. 50, pp. 1972-1981.

Faye G.H., Manning P.G., Nickel E.H. (1968) The polarized optical absorption spectra of tourmaline, cordierite, chloritoid and vivianite: ferrous-ferric electronic interaction as a source of pleochroism. American Mineralogist, Vol. 53, pp. 1174-1201.

Ferguson J., Fielding P.E. (1971) The origins of the colours of yellow, green and blue sapphires. Chemical Physics Letters, Vol. 10, No. 3, pp. 262-265.

Fox D.L., Brown F.A., Losey G.S. (1983) Coloration, biological. New Encyclopaedia Brittanica, Encyclopaedia Brittanica, Chicago, IL, p. 918

Fritsch E. (1985) La couleur des minéraux et des gemmes, deuxième partie. Monde et Minéraux, Vol. 69, pp. 12-17.

Fritsch E., Rossman G.R. (1987) An update on color in gems. Part 1: Introduction and colors caused by dispersed metal ions. Gems e) Gemology, Vol. 23, No. 3, pp. 126-139.

Goldman D.S., Rossman G.R., Parkin K.M. (1978) Channel constituents in beryl. Physics and Chemistry of Minerals, Vol. 3, pp. 225-235.

Griffiths I. (1981) Recent developments in the colour and constitution of organic dyes. Review of Progress in Coloration and Related Topics, Vol. 11, pp. 37-57.

Harder H., Schneider A. (1986) Isomorpher Einbau von Eisen und Titan zur Erklärung der blauen Farbe von Rutil- und Spinell-haltigen seidig weissen Korunden nach einer
Warmebehandlung. Neues Jahrbuch für Mineralogie, Monatshefte, Vol. 5, pp. 209-218.

Hofmeister A.M., Rossman G.R. (1985) A spectroscopic study of irradiation coloring of amazonite: Structurally hydrous, Pb-bearing feldspar. American Mineralogist, Vol. 70, pp. 794-804.

Hoimeister A.M., Rossman G.R. (1986) A spectroscopic study of blue radiation coloring in plagioclase. American Mineralogist, Vol. 71, pp. 95-98.

Kittel C. (1980) Introduction to Solid State Physics, 4th ed. John Wiley \& Sons, New York.

Loeffler B.M., Burns R.G. (1976) Shedding light on the color of gems and minerals. American Scientist, Vol. 64, No. 6, pp. 636-647

Manning P.G. (1973) Effect of second nearest-neighbour interaction on $\mathrm{Mn}^{3}+$ absorption in pink and black tourmaline. Canadian Mineralogist, Vol. 11, pp. 971-977.

Marfunin A.S. \{1979) Spectroscopy, Luminescence and Radiation Centers in Minerals. Translated by V. V. Schiffer, Springer Verlag, Berlin.

Mattson S.M., Rossman G.R. (1984) Ferric iron in tourmaline. Physics and Chemistry of Minerals, Vol. 11, pp. 225-234.

Mattson S.M. Rossman G.R. (1987a) $\mathrm{Fe}^{2+}-\mathrm{Fe}^{3+}$ interactions in tourmaline. Physics and Chemistry of Minerals, Vol. 14, pp. 163-171.

Mattson S.M., Rossman G.R. (1987b) ldentifying characteristics of charge transfer transitions in minerals. Physics and Chemistry of Minerals, Vol. 14, pp. 94-99.

Moore R.K., White WB. (1971) Intervalence electron transfer effects in the spectra of the melanite garnets. American Mineralogist, Vol. 56, pp. 826-840.

Nassau K. (1975) The origins of color in gems and minerals. Part 2. Gems \&) Gemology, Vol. 15, No. 1, pp. 2-11.

Nassau K., Prescott, B.E., Wood D.L. (1976) The deep-blue Maxixe type color center in beryl. American Mineralogist, Vol. 6I, pp. 100-107.

Nassau K. (1984) Gemstone Enhancement. Butterworths, Stoneham, MA.

Nassau K. (1985) Altering the color of topaz. Gems \&emology, Vol. 21, No. 1, pp. 26-34.

Nassau K. (1987) The seven types of yellow sapphire and their stability to light. Gems \&) Gemology, Vol. 23, No. 4, pp. 222-231.

Parkin K.M., Loeffler B.M., Burns R.G. (1977) Mossbatier spectra of kyanite, aquamarine, and cordierite showing intervalence charge transfer. Physics and Chemistry of Minerals, Vol. 1, pp. 301-311.

Partlow D.P., Cohen A.J. \{1986) Optical studies of biaxial Alrelated color centers in smoky quartz. American Mineralogist, Vol. 71 , pp. 589-598.

Petrov I. (1977) Farbeuntersuchungen an Topas. Neues $7 a h r-$ buch für Mineralogie Abhandlungen, Vol. 130, No. 3, pp. 288-302.

Pizani P.S., Terrile M.C., Farach H.A., Poole C.P. Jr. (1985) Color centers in sodalite. American Mineralogist, Vol. 70, pp. $1186-1192$.

Rossman G.R. (1974) Lavender jade. The optical spectrum of $\mathrm{Fe}^{3+}$ and $\mathrm{Fe}^{2+}-\mathrm{Fe}^{3+}$ intervalence charge transfer in jadeite from Burma. American Mineralogist, Vol. 59, pp. $868-870$.

Rossman G.R., Mattson S.M. (1986) Yellow Mn-rich elbaite with $\mathrm{Mn}$-Ti intervalence charge transfer. American Mineralogist, Vol. 71, pp. 599-602.

Rossman G.R., Qiu Y. (1982) Radioactive irradiated spodumene. Gems \&) Gemology, Vol. 18, No. 2, pp. 87-90.

Samoilovich M.I., Tsinober L.I., Kreishop V.N. (1969) The nature of radiation-produced citrine coloration in quartz. Soviet Physics-Crystallography, Vol. 13, No. 4, pp. 626-628.

Schiffmann C.A. (1981) Unstable colour in a yellow sapphire 
from Sri Lanka. Journal of Gemmology, Vol. 17, No. 8, pp. 615-618.

Sehmetzer K., Bosshart G., Hänni H.A. (1982) Naturfarbene und behandelte gelbe und orange braune Sapphire. Zeitschrift der Deutschen Gemmologischen Gesellschaft, Vol. 31, No. 4, pp. 265-279.

Schmetzer K. (1986) Farbung und Bestrahlungsschaden in elektronenbestrahlten blauen Topasen. Zeitschrift der Deutschen Germmologischen Gesellschaft, Vol. 35, No. 1/2, pp. 27-38.

Schmetzer K. (1987) Irradiation-induced blue color in topaz. Naturwissenschaften, Vol. 74, pp. 136-137.

Smith G., Strens R.G.J. (1976) Intervalence transfer absorption in some silicate, oxide and phosphate minerals. In R. G. J. Strens, Ed., Physics and Chemistry of Minerals and Rocks, John Wiley \& Sons, New York, pp. 583-612.

Smith G. (1977) Low temperature optical studies of metalmetal charge transfer transitions in various minerals. Canadian Mineralogist, Vol. 10, pp. 500-507.

Tippins H.H. (1970) Charge transfer spectra of transition metal ions in corundum. Physical Review B, Vol. 1, No. 1, pp. $126-135$

Wood D.L., Nassau K. (1968) The characterization of beryl and emerald by visible and infrared absorption spectroscopy. American Mineralogist, Vol. 53, pp. 777-800.

The Gemological Institute of America extends its sincerest appreciation to all of the people and firms who contributed to the activities of the Institute through donations of gemstones and other gemological materials. We are pleased to acknowledge many of you below.

Gary Abbott
Arnold Arem
Lilliam Armstrong
Don Bachner
Pierre Bariand
Bill Barker
Arnold Baron
Luiz Barreto da Silva
Martin Bell
Mel Belsky
Joe Best
Gary Bowersox
David A. Brackna
Connie Buchanan
Douglas Burleigh
David Callaghan
Ricardo Rivera Castrillon
Dick Cecil
John Chadwick
Jim Clanin
Tony Cotner
Barton Curran
Archie Curtis
Louise Darby
Dino DeGhionno
"Robert Dunnigan
John Emmett
Earl Ferguson
Jimmy Flynn

\author{
Sondra Francis \\ $\mathrm{Si}$ and Ann Frazier \\ * Charles Fryer \\ Gem Lab of L.A. \\ David M. Glickman \\ Frank Goodden Co. \\ Edward and Sandra Gottfried \\ Cal and Kerith Graeber \\ Arthur Grant \\ Michael Gray \\ Rak Hansawek \\ -Ann Hardy \\ *Taketoshi Hayakawa \\ Milton D. Heifetz \\ William D. Hoefer, Jr. \\ David Humphrey \\ Aage Jensen \\ Bernadine Johnston \\ Joe Kalman \\ Henry Kennedy \\ Bert T. King \\ Frank Knechtal \\ John Koivula \\ *Dorothy Komarow \\ (in memory of Bert Komarow) \\ Harold Kopp \\ Glenn Landis \\ Tony and Nelson Leung \\ Howard A. Marcon
}

Geri, S. Mayers

William A. Mosher

Kurt Nassau

Clinton D. Nelson

Ramon Ortiz

*Francine Payette

Julius Petsch, Jr.

William W. Pinch

Charles A. and Lois F. Pippert

Charles and Kay Pollster

(in memory of William Ilfeld)

Gary Roskin

Robert Saling

Gary Schalla

Tim Sherburn

"James Shigley

Dan Sofia

Robert F. Steigrad

Carol Stockton

Ronald H. Tanaka

Andrew Taylor

Murray Thompson

Sharon Thompson

Roger Trontz

Clay Tudor II

Steve Ulatowski

" William Videto

Gary Werner

Anna Stina Wrangel

"Denotes book donation to GIA Library

- Denotes donation of books and gemstone materials 